\title{
Adaptasi individual dan kolektif: Respons masyarakat Indonesia menghadapi pandemi COVID-19
}

\author{
Wenty Marina Minza ${ }^{1}$, Faturochman ${ }^{1}$, Syurawasti Muhiddin² \& Wahyu Jati \\ Anggoro ${ }^{2}$ \\ ${ }^{1}$ Fakultas Psikologi, Universitas Gadjah Mada, Yogyakarta \\ ${ }^{2}$ Center for Indigenous and Cultural Psychology, Fakultas Psikologi, Universitas Gadjah Mada
}

\begin{abstract}
Abstrak
Pandemi COVID-19 telah memberikan dampak pada berbagai aspek kehidupan manusia. Hal ini membuat manusia melakukan adaptasi dalam rangka menyesuaikan diri dengan kondisi yang ada. Penelitian ini bertujuan untuk mengeksplorasi proses adaptasi masyarakat dalam menghadapi pandemi COVID-19 di Indonesia. Metode penelitian yang digunakan adalah kuantitatif deskriptif. Sebanyak 544 responden yang merupakan Warga Negara Indonesia mengisi skala persepsi sosial terhadap risiko dan penyebaran COVID-19 secara daring melalui google form. Hasil penelitian berfokus pada respons adaptif masyarakat baik berupa persepsi maupun perilaku. Dari penelitian ini, ditemukan bahwa adaptasi masyarakat menghadapi COVID-19 tidak hanya terjadi pada level individual melainkan juga pada level kolektif. Pada level individual, ditemukan dua bentuk adaptasi psikologis, yaitu yang bersifat aktif dan pasif. Pada level kolektif, ditemukan bahwa koping kolektif adalah bentuk adaptasi sosial-psikologis yang penting dengan solidaritas sebagai esensi dari proses tersebut.
\end{abstract}

Kata kunci: Adaptasi, Individual, Kolektif, Pandemi COVID-19

\begin{abstract}
The COVID-19 pandemic has given an impact on various aspects of human life forcing humans to adapt to the existing condition. This study aimed to explore the adaptation process toward the COVID-19 pandemic in Indonesia. Research method applied was quantitative-descriptive. A total of 544 Indonesian citizens filled out an online social perception toward risk and spread of COVID-19 scale through google form. The results focused on the adaptive response of the community consisting of both perceptions and behaviors. This study found that the adaptation of the society to deal with COVID-19 did not only occurs at the individual level but also at the collective level. At the individual level, there were two kinds of psychological adaptation found namely active and passive. At the collective level, this study suggested that collective coping is an important form of social-psychological adaptation in which solidarity is the essence of the process.
\end{abstract}

Keywords: Adaptation, Collective, Individual, Pandemic COVID-19

\section{Pendahuluan}

Pandemi COVID-19 diketahui berdampak pada aspek psikologis manusia. Hal ini didasarkan pada beberapa temuan penelitian tentang COVID-19 dan kaitannya dengan perilaku manusia seperti dampaknya terhadap aspek emosi (Gerhold, 2020; Li, dkk., 2020), persepsi sosial dan risiko (Atchison, dkk., 2020; Lopez, dkk., 2020; Wise, dkk., 2020), paranoia dan panik (Ho, Chee dan Ho, 2020), serta kesepian (Berg-Weger \& Morley, 2020). Rasa takut merupakan emosi yang sering muncul saat manusia dihadapkan pada sebuah wabah. Ketakutan tersebut sering kali menular

Naskah masuk: 1 April 2021

Naskah diterima: 3 November 2021 dari satu individu ke individu yang lain (Kramer, Guillory dan Hancock, 2014), sehingga kondisi ini akan membuat wabah tampak semakin mengancam.

Perilaku manusia terhadap ancaman selalu menarik untuk ditelaah lebih jauh. Manusia sebagaimana organisme lain juga akan memiliki pola perilaku tertentu ketika dihadapkan pada ancaman ekologis (LeDoux, 2012; Mobbs, dkk., 2015). Becker (2007) menggambarkan bahwa individu sedapat mungkin akan menghindari atau mengurangi hal-hal yang bisa mengancam kelangsungan hidupnya. Dalam konteks pandemi, wabah COVID19 merupakan ancaman yang jelas dengan bukti ratusan ribu kematian (WHO, 2020).

*Fakultas Psikologi, Universitas Gadjah Mada, Jl. Sosio Humaniora Bulaksumur, Sleman, Yogyakarta 55281 E-mail: wminza@ugm.ac.id 
Sebagaimana yang dijelaskan dalam teori tingkat adaptasi Helson (1964), setiap organisme akan melakukan suatu mekanisme adaptasi pada saat menghadapi stimulus-stimulus dari lingkungannya. Berawal dari teori evolusi, konsep adaptasi telah digunakan di berbagai disiplin ilmu. Dari arti katanya, istilah adaptasi digunakan untuk menunjukkan upaya menyesuaikan diri dengan situasi (Simonet \& Duchemin, 2010). Dalam disiplin ilmu psikologi, adaptasi diartikan sebagai proses yang melingkupi interaksi yang terus-menerus antara individu dengan lingkungan yang dinamis, tempat dirinya mengembangkan keseimbangan dan membangun interaksi (Jakubowicz dalam Simonet \& Duchemin, 2010). Adaptasi juga diartikan sebagai suatu proses jangka panjang yang dapat menghasilkan perubahan perilaku dan praktik tertentu untuk mengurangi hal-hal yang mendasari adanya kerentanan dan dampak negatif tertentu (Yang \& Andriesse, 2020).

Terdapat beberapa jenis adaptasi yang dikelompokkan dari beberapa literatur. Adaptasi fisiologis berkaitan dengan respons tubuh atau fisik terhadap stimulus lingkungan, sementara adaptasi psikologis merupakan respons psikologis yang juga diartikan sebagai mekanisme koping. Selanjutnya, terdapat istilah adaptasi perkembangan yang dikaitkan dengan respons terhadap tekanan karena tugas-tugas perkembangan. Adaptasi lainnya adalah adaptasi sosial-budaya, dikaitkan dengan penyesuaian terhadap kondisi sosial-budaya seperti nilai dan norma. Terakhir, adaptasi spiritual yang berhubungan dengan respons terhadap tekanan dengan menggunakan dimensi spiritual (Gerungan, 2006; Nasir \& Muhith, 2011; Safarino \& Smith, 2014).

\section{Strategi koping sebagai adaptasi sosial- psikologis}

Pandemi COVID-19 yang menimbulkan kecemasan dan stres dapat direspon oleh individu sebagai bentuk strategi koping. Seperti yang disebutkan sebelumnya, mekanisme koping merujuk pada adaptasi psikologis. Strategi koping dapat diartikan sebagai upaya kognitif dan perilaku untuk memodulasi tuntutan internal dan eksternal yang dinilai melebihi sumber daya pribadi (Endler \& Parker, 1990; Lazarus \& Folkman, 1984, dalam Smith, Saklofske, Keefer \& Tremblay, 2016). Penelitian menunjukkan strategi koping tertentu mengurangi stres dan mempromosikan hasil psikologis yang positif, di sisi lain juga dapat memperburuk stres dan mempromosikan hasil psikologis yang negatif (Endler \& Parker, 1994; Parker \& Endler, 1992 dalam Smith, dkk., 2016). Meskipun demikian, manfaat dari setiap strategi koping kemungkinan bergan- tung pada sejumlah faktor lain, termasuk persepsi terhadap pengendalian stres, ketersediaan sumber daya yang cukup untuk mengatasi sumber stres, dan hakikat dari hasil atau dampaknya (Folkman \& Moskowitz, 2000; Smith, dkk., 2016). Secara umum, pandemi telah memberikan efek yang besar pada ekonomi dan infrastruktur masyarakat secara lebih luas (Taylor, 2019). Dimulai dari masyarakat yang terinfeksi virus, kemudian dapat mengalami sakit fisik maupun psikologis dan tidak dapat melakukan pekerjaanpekerjaan mereka sehingga memengaruhi pelayanan esensial secara luas (Shultz, Baingana, \& Neria, 2015). Oleh karena itu, adaptasi psikologis yang memberikan hasil positif diperlukan agar masyarakat tetap produktif dan mencegahnya untuk mengalami masalah psikologis yang lebih berat seperti stres, kecemasan dan depresi. Dengan demikian, masyarakat tetap dapat mempertahankan kondisi ekonomi dan kesejahteraannya secara umum. Hal ini pada gilirannya dapat mengurangi beban ekonomi negara akibat kondisi kesehatan yang menurun serta kemiskinan itu sendiri, sehingga mendukung dan menguatkan negara menghadapi Pandemi COVID-19.

Beberapa penelitian di Indonesia telah menunjukkan proses adaptasi menghadapi COVID19. Proses adaptasi tersebut terutama merupakan proses adaptasi psikologis dalam hal ini strategi koping. Dari temuan yang ada, strategi koping yang diadopsi di Indonesia berfokus pada emosi seperti penilaian diri, kontrol diri dan berdoa, maupun dengan menitikberatkan pada penyelesaian masalah, seperti pemecahan masalah yang terencana dan pencarian dukungan sosial (Kristamuliana \& Simak, 2020; Masitoh, 2020; Nasrudin, dkk., 2020).

Penelitian-penelitian yang telah dilakukan tersebut umumnya menekankan pada adaptasi psikologis yang dilakukan pada level individu. Oleh karena itu, penelitian ini bertujuan untuk mengeksplorasi proses adaptasi masyarakat Indonesia terhadap Pandemi COVID-19 secara umum pada masa-masa awal kemunculannya di Indonesia, tidak saja pada level individu, tetapi juga pada level kelompok. Hasil penelitian ini dapat memberikan pemahaman tentang cara ataupun pola masyarakat Indonesia merespon kondisi ketidakpastian dari perspektif adaptasi psikologis.

\section{Metode Penelitian}

\section{Partisipan}

Responden merupakan masyarakat Indonesia tanpa adanya kriteria khusus, yang dipilih dengan teknik convenience sampling. Sebanyak 544 responden mengisi survei melalui 
Google Form. Responden penelitian dijabarkan berdasarkan beberapa variabel demografis. Sebanyak $63 \%$ responden adalah perempuan (lakilaki $=37 \%$ ). Sebagian besar responden berusia 21 hingga 40 tahun (66\%), sebanyak 20\% responden berusia diatas 40 tahun, sementara itu hanya sekitar 14\% yang berusia di bawah 20 tahun. Sejalan dengan variabel usia, sebagian besar responden menempuh pendidikan $\mathrm{S} 1$ ataupun Diploma (60\%). Responden yang menjalani pendidikan pascasarjana menempati urutan kedua (31\%). Hanya sebanyak 9\% responden yang merupakan pelajar, dalam hal ini siswa SMA. Berdasarkan wilayah tempat tinggalnya, sebanyak 43\% responden tinggal di kota menengah; 39\% berada di kota besar. Hanya 6\% responden yang hidup di kota kecil dan 3\% responden di kota terisolasi. Selanjutnya, responden juga dibedakan berdasarkan risiko wilayah yang mana sebagian besar responden (71\%) berada di wilayah berisiko terkait penyebaran COVID-19 (ditinjau dari penderita yang meninggal karena terkonfirmasi$6,1 \%$ meninggal dari yang terkonfirmasi), sisanya berada di wilayah tidak berisiko.

\section{Desain dan prosedur}

Penelitian ini menggunakan metode penelitian kuantitatif-deskriptif berupa survei eksploratori yang disebarkan daring melalui berbagai platform media sosial. Tidak ada pertanyaan terkait dengan riwayat medis responden serta informasi sensitif lainnya. Responden mengisi lembar kesediaan menjadi responden di awal kuesioner, sebelum menjawab pertanyaan-pertanyaan survei yang berupa skala dalam beberapa bagian. Pada akhir kuesioner, responden mengisi beberapa data demografi. Pengambilan data dilakukan selama sekitar dua bulan selama masa tanggap darurat COVID-19 di Indonesia.

\section{Instrumen pengambilan data}

Survei menggunakan instrumen alat ukur, yaitu Skala Persepsi Sosial terhadap Risiko dan Penyebaran COVID-19 yang disusun oleh tim peneliti Universitá Giustino Fortunato, Italia (2020) berdasarkan sejumlah aspek-aspek psikologis dan sosial yang secara umum terdampak oleh Pandemi (Taylor, 2019). Skala diterjemahkan dalam bahasa Indonesia oleh Dr. Wenty Marina Minza, M.A. Kuesioner tersebut terdiri atas 97 aitem (skala 1 - 5) dengan beberapa dimensi; dalam artikel ini analisis hanya dilakukan pada aitem yang berhubungan dengan respons masyarkat, baik respons emosi, kognitif maupun perilaku. Berikut adalah beberapa contoh aitem: "Saya takut terhadap apa yang akan terjadi dalam beberapa hari ke depan"; "Saya mencari infor- masi mengenai virus Corona melalui berbagai alternatif sumber informasi"; "Saya merasa lebih dekat dengan Tuhan"; "Saya mejaga jarak dengan orang lain dan menghindari kerumuman."

Berkaitan dengan validitas alat ukur, instrumen survei tersebut dievaluasi kesahihannya menggunakan strategi pembuktian validitas isi (Furr \& Bacharach, 2013). Setiap aitem pertanyaan dinilai isinya secara logis oleh tiga ahli dari Indonesia yang ditentukan oleh peneliti. Berdasarkan penilaian tersebut, instrumen penelitian telah dinilai layak dan sesuai untuk mengukur dimensi yang dimaksud, termasuk dalam konteks masyarakat Indonesia. Aitem-aitem pernyataan dalam skala juga dinilai bersifat umum untuk memahami reaksi dan respons masyarakat dalam menghadapi wabah pada berbagai konteks. Setelah melakukan pengambilan data, uji reliabilitas skala dilakukan terhadap seluruh aitem; menghasilkan nilai Cronbach Alpha sebesar 0,924 .

\section{Teknik analisis}

Data dianalisis dengan analisis statistik deskriptif dalam bentuk perbandingan rata-rata (mean) angka skala dari beberapa aitem yang memiliki aspek yang sama, serta perbandingan persentase angka skala yang dipilih dalam satu aitem tertentu. Beberapa aitem juga dianalisis dengan uji $t$, yaitu aitem yang terkait dengan upaya perlindungan, penanganan bersama, kepatuhan terhadap pihak berwenang, serta keyakinan recovery.

\section{Hasil Penelitian}

\section{COVID-19 dan peningkatan kecemasan.}

Situasi pandemi telah menimbulkan kecemasan bagi masyarakat. Hal yang dicemaskan oleh responden dalam konteks COVID-19 ini dapat dilihat pada Gambar 1, yang menunjukkan bahwa responden merasakan kecemasan tinggi terkait dengan kemungkinan jatuh sakit (3.64) dan ketidakmampuan membantu orang-orang dekat yang dicintai (3.65). Kecemasan pada level sedang cenderung dikaitkan dengan ketidakpastian dan kejadian-kejadian yang akan datang (3.13). Sementara itu, kecemasan rendah berkaitan dengan kecemasan akan kehilangan kontrol (2.89). Hal ini dapat mengindikasikan bahwa mereka yang memiliki kecemasan tinggi dan sedang kemungkinan merasa tidak memiliki kontrol akan kejadian pandemi ini. Sebaliknya, mereka yang memiliki kecemasan rendah kemungkinan merasa memiliki kontrol yang lebih besar. 


\section{Gambar 1}

Kategori sumber kecemasan

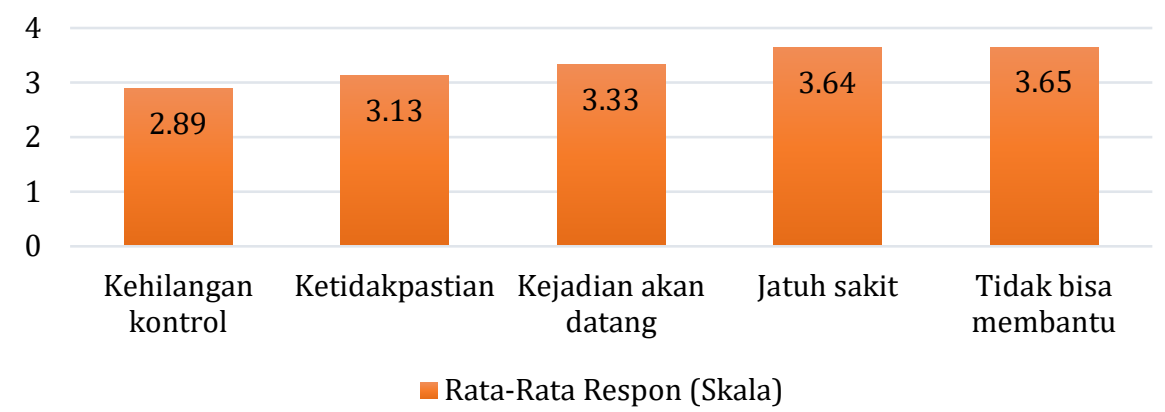

\section{Gambar 2}

Kekhawatiran bahwa COVID-19 sebagai awal masalah besar lainnya.

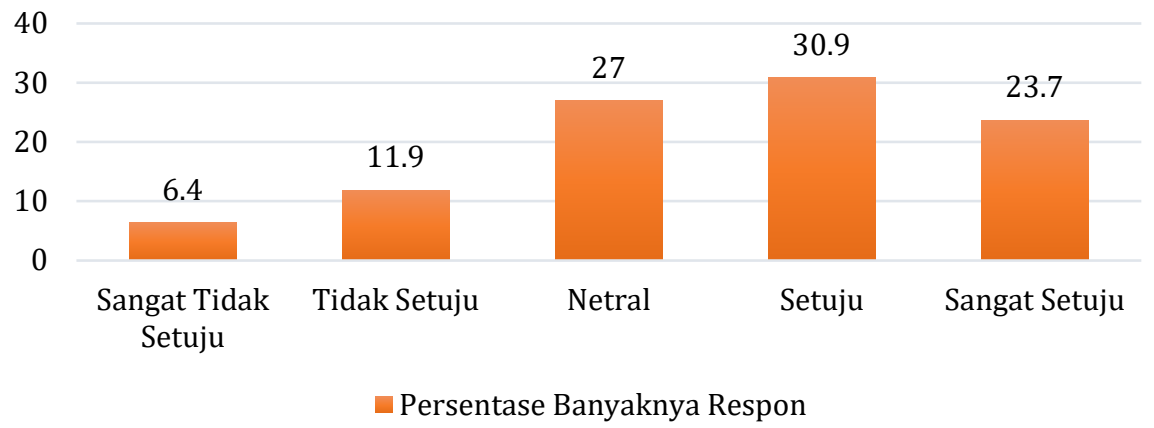

Selain di level individu, kecemasan terhadap pandemi ini juga dapat berkaitan dengan persepsi yang dimiliki seseorang terhadap kejadian di level yang lebih makro. Sebagian besar $(54,6 \%)$ responden memiliki kekhawatiran bahwa pandemi ini merupakan awal dari masalah besar lainnya yang akan dihadapi manusia seperti yang terlihat pada Gambar 2. Selain memiliki dampak terhadap kesehatan individu, sebagian besar responden menganggap COVID-19 akan membawa dampak pada perekonomian di masa yang akan datang, baik ekonomi lokal (41,4\%), nasional $(44,7 \%)$, maupun global (39\%) sebagaimana yang terlihat pada Gambar 3.

\section{Gambar 3}

Kekhawatiran terhadap Masa Depan Ekonomi Lokal (I), Nasional (II), dan Global (III).

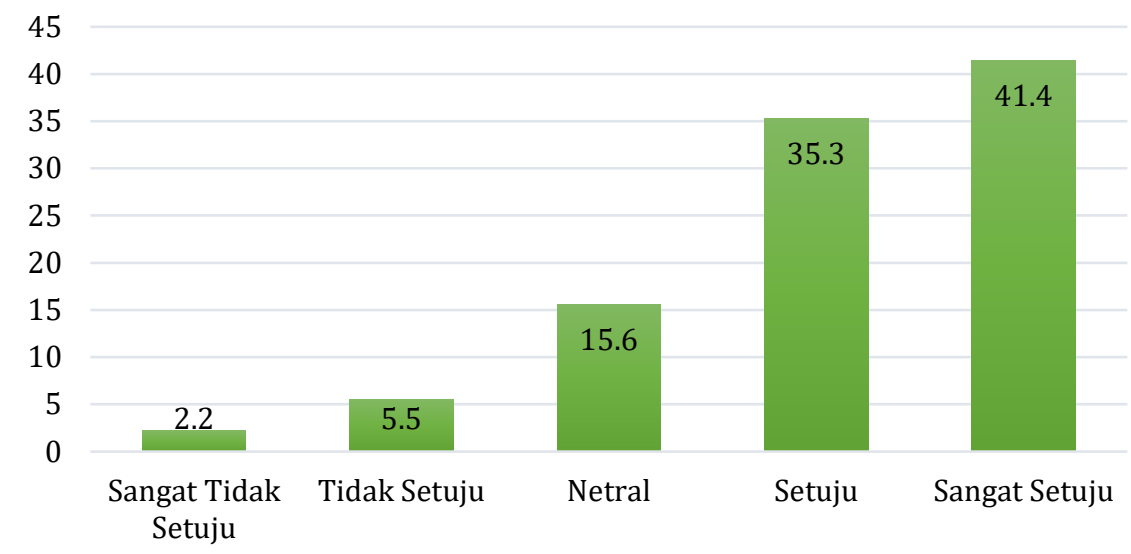

- Persentase Banyaknya Respon 


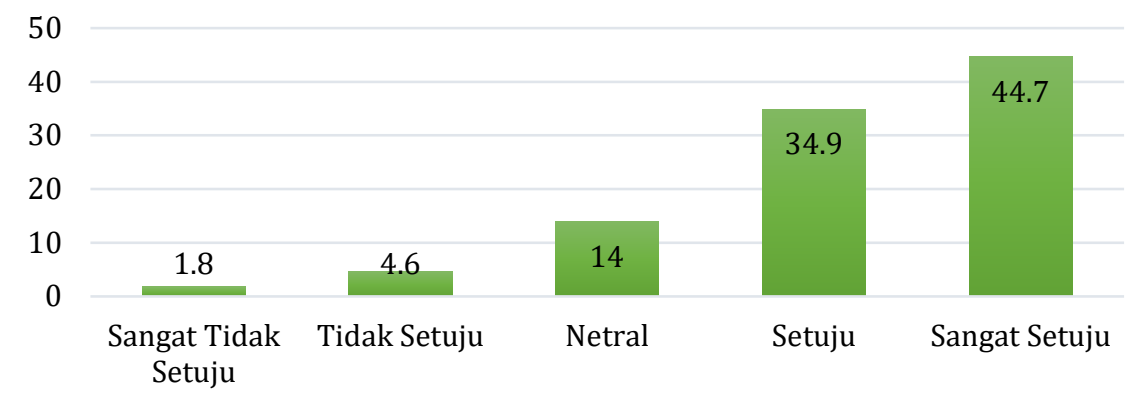

- Persentase Banyaknya Respon

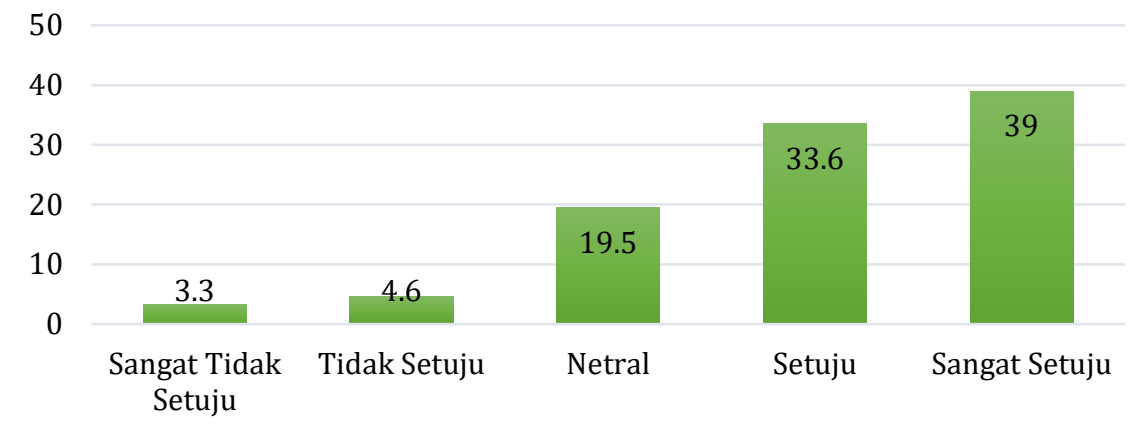

- Persentase Banyaknya Respon

\section{Upaya adaptasi individu}

Dalam kondisi seperti ini, berbagai upaya adaptasi dilakukan oleh masyarakat dengan berpedoman dari himbauan pemerintah. Berikut beberapa bentuk adaptasi yang dilakukan.

Menjalankan protokol kesehatan: Menjaga jarak dan menghindari kerumunan, serta memakai masker. Protokol kesehatan ini merupakan langkah pencegahan yang paling umum dilakukan dalam mencegah COVID-19 yang menjadi aturan protokol kesehatan yang diatur oleh pemerintah. Gambar 4 menunjukkan bahwa bahwa mayoritas responden telah berusaha menjaga jarak fisik dan menghindari kerumunan ketika keluar dari rumah (59,9\%). Meski demikian, penggunaan masker tidak begitu konsisten sebagaimana menjaga jarak; terlihat dari pola respons yang masih menyebar di semua kategori pilihan jawaban pada Gambar 5.

\section{Gambar 4}

Menjaga jarak dan menghindari kerumuman

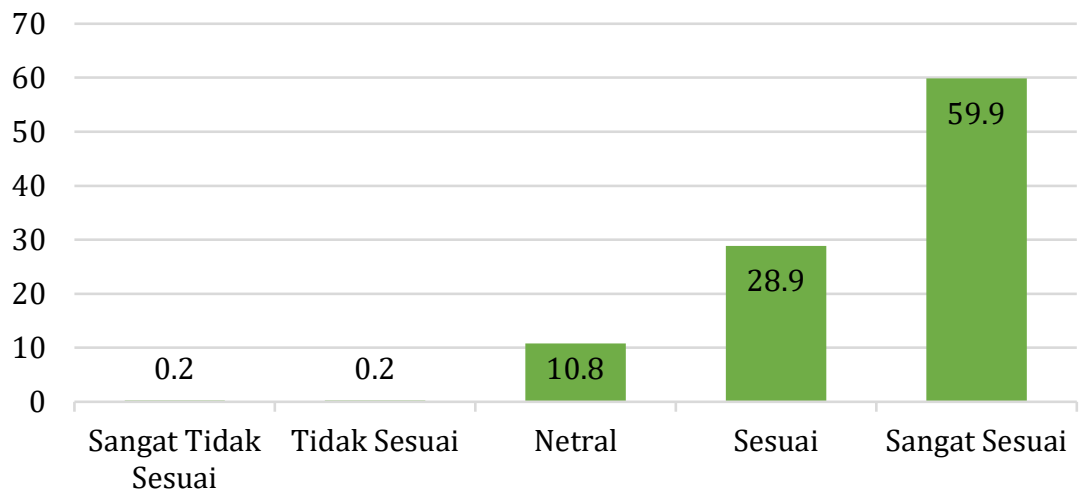

- Persentase Banyaknya Respon 


\section{Gambar 5}

Menggunakan masker di luar rumah

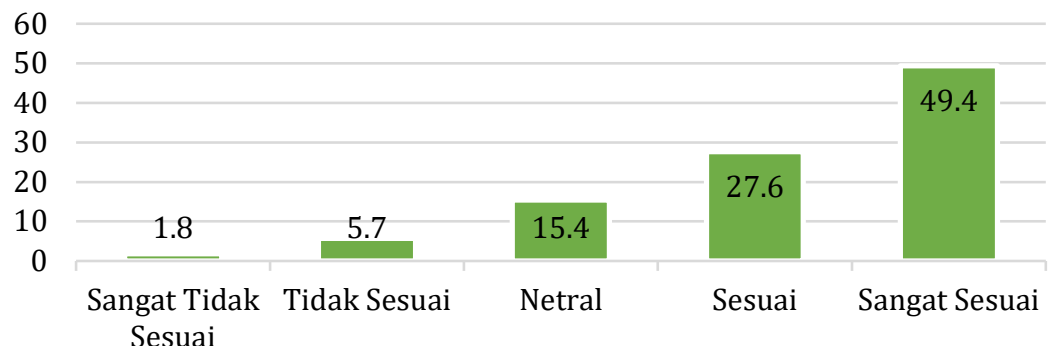

- Persentase Banyaknya Respon

Mencari informasi terkait COVID-19. Pencarian informasi menjadi salah satu jalan untuk membantu pengambilan keputusan dalam menghadapi pandemi yang menimbulkan kecemasan. Sumber informasi yang beragam memberi kesempatan bagi masyarakat untuk memilih berbagai alternatif yang akan menjadi panduan dalam menghadapi ancaman COVID-19. Gambar 6 menunjukkan bahwa sumber informasi yang paling sering diakses responden untuk mendapatkan informasi tentang COVID-19 adalah internet $(4,28)$. Setelah internet, sumber informasi lain yang menjadi andalan adalah sumber resmi seperti dari pemerintah $(4,11)$ dan informasi dari media cetak $(3,74)$. Meski demikian, taraf kepercayaan responden terhadap informasi COVID-19 ada pada tingkat sedang $(36,9 \%)$, seperti yang dilihat pada Gambar 7. Artinya, meski akses terhadap pilihan sumber informasi mengenai COVID-19 cukup besar, tidak berarti bahwa sumber informasi yang dipilih dianggap memiliki kredibilitas tinggi.

\section{Gambar 6}

Sumber informasi COVID-19

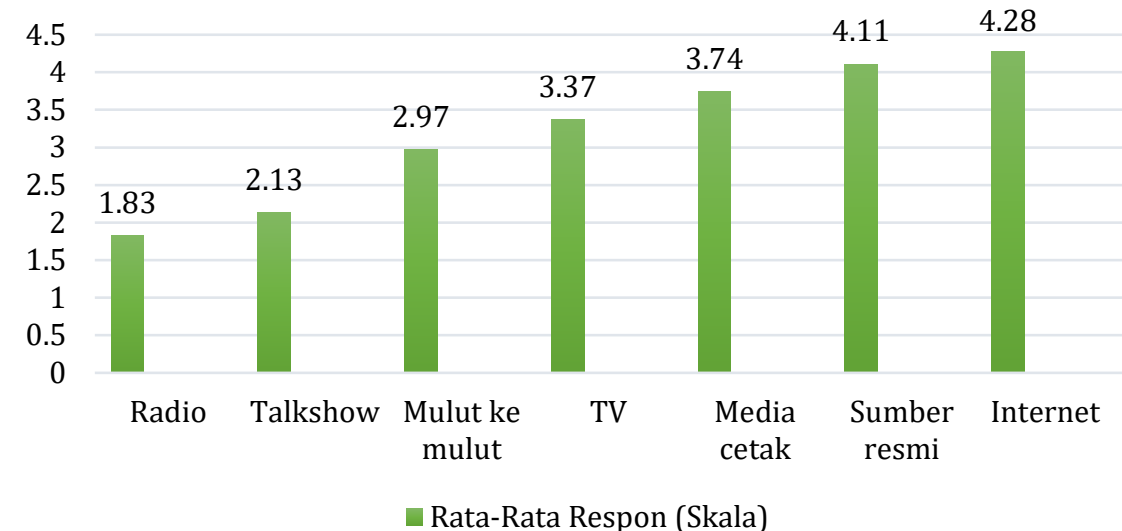

\section{Gambar 7}

Kejelasan informasi tentang COVID-19

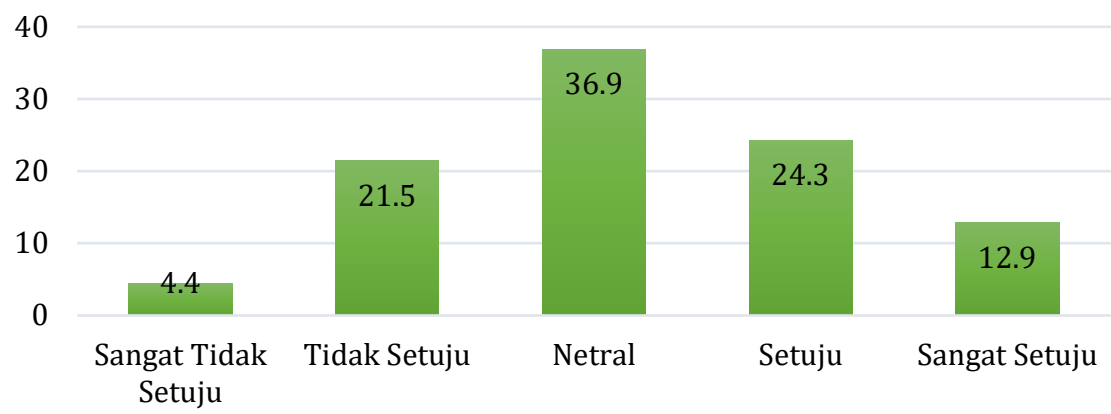

- Persentase Banyaknya Respon 
Menjaga relasi yang berbasis jaringan (Online). Upaya yang dilakukan responden untuk tetap berelasi dengan menjaga jarak atau menghindari kontak fisik langsung, ditunjukkan pada Gambar 8. Alternatif berelasi yang dipilih responden adalah dengan media sosial berbasis jaringan. Alternatif ini dianggap sebagai pengganti komunikasi tatap muka konvensional, dengan tingkat preferensi yang relatif sangat tinggi $(59,4 \%)$.

Melaporkan kasus COVID-19. Pelaporan terhadap kasus COVID-19 juga merupakan upaya yang diperlukan untuk menghadapi pandemi ini.
Gambar 9 menunjukkan bahwa sebagian besar responden akan cenderung melaporkan kasus COVID-19 apabila kasus tersebut menimpa keluarga dekat seperti orang tua $(4,47)$, saudara $(4,47)$, dan anak $(4,43)$. Seseorang juga akan cenderung melaporkan teman $(4,32)$ dan kolega $(4,26)$ jika dibandingkan dengan orang yang tidak dikenal ataupun orang asing. Ini menunjukkan bahwa pelaporan COVID-19 di Indonesia tidak banyak terkait dengan stereotyping dan stigma, tetapi dengan kepedulian terhadap keamanan dan kesehatan orang terdekat. Semakin dekat jarak personal, semakin besar kemungkinan pelaporan.

\section{Gambar 8}

Alternatif platform media sosial untuk berelasi

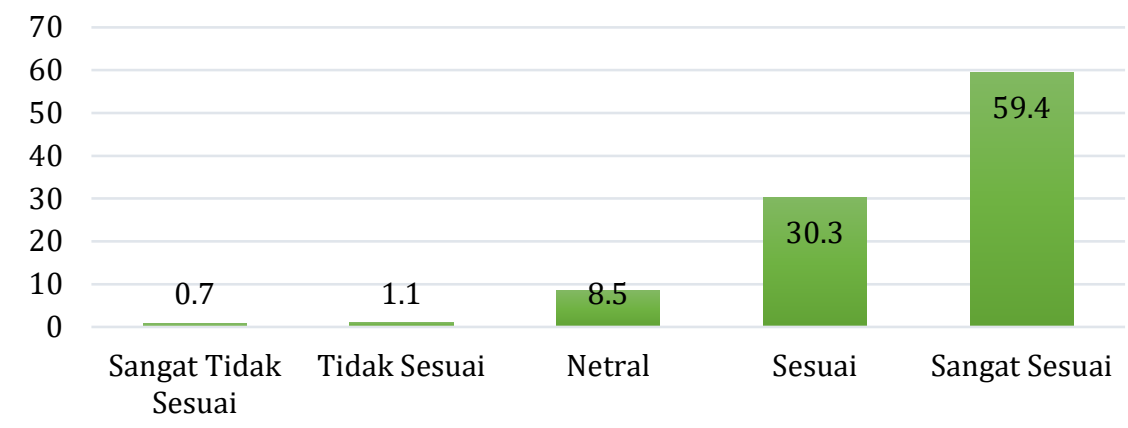

- Persentase Banyaknya Respon

\section{Gambar 9}

Kecenderungan pelaporan kasus COVID-19.

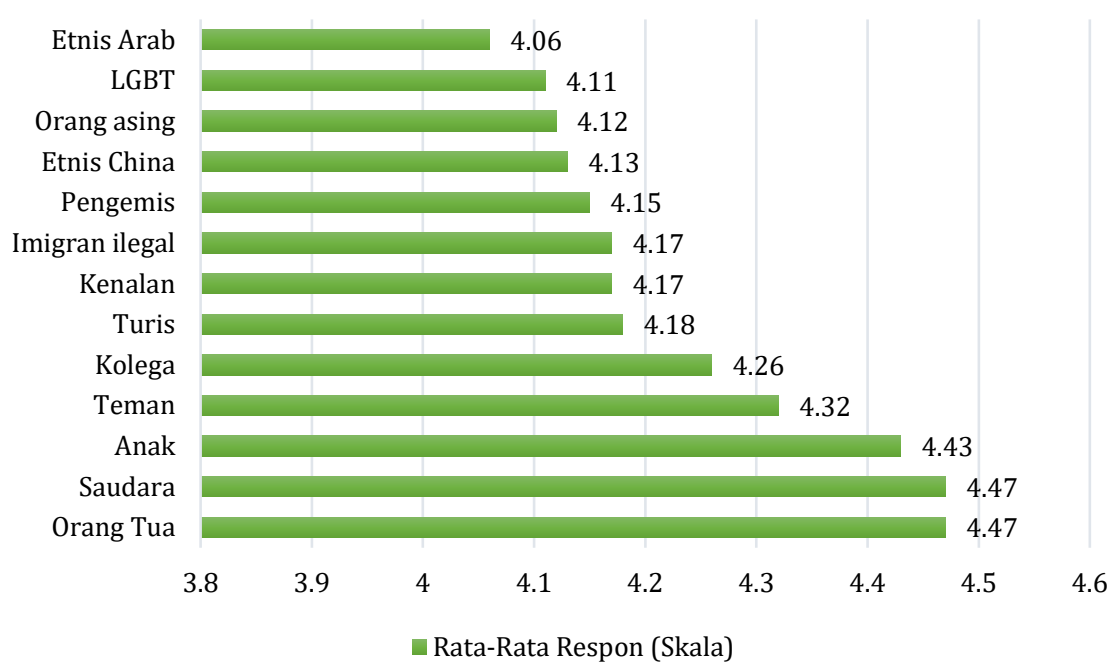

Menjaga optimisme. Berkaitan dengan aspek kognitif, responden memiliki optimisme yang cukup tinggi terhadap kemungkinan sembuh (recovery). Responden meyakini bahwa persoalan akibat COVID-19 akan membaik dalam beberapa bulan $(4,25)$ dan bukan dalam beberapa tahun ke depan $(2,68) ; \mathrm{t}(524)=20,01$; $\mathrm{p}<0,05$; lihat Gambar 10). Hal ini juga merujuk pada persepsi yang dapat mempengaruhi respons masyarakat. 
Gambar 10

Keyakinan recovery

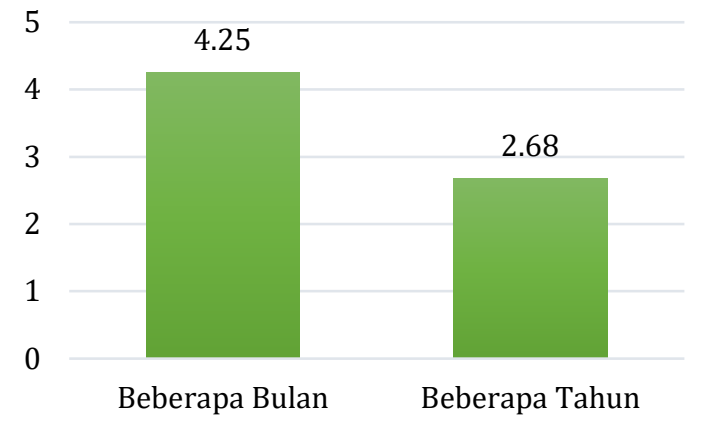

- Rata-Rata Respon (Skala)

Mendekatkan diri pada Tuhan. Dalam menghadapi pandemi ini, sebagian besar responden mempercayai bahwa kejadian ini merupakan bagian dari rencana Tuhan $(46,2 \%)$, sebagaimana yang terlihat pada Gambar 11. Hal ini sejalan dengan kedekatan individu dengan Tuhan, seperti yang terlihat pada Gambar 12, di mana sebagian besar orang-orang merasa lebih dekat dengan Tuhan $(36,8 \%)$ di masa pandemi ini.

\section{Gambar 11}

Kepercayaan pada rencana Tuhan

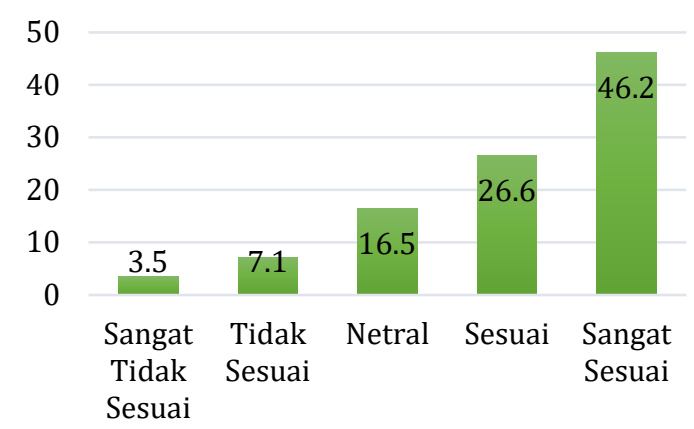

- Persentase Banyaknya Respon
Gambar 12

Kedekatan dengan Tuhan

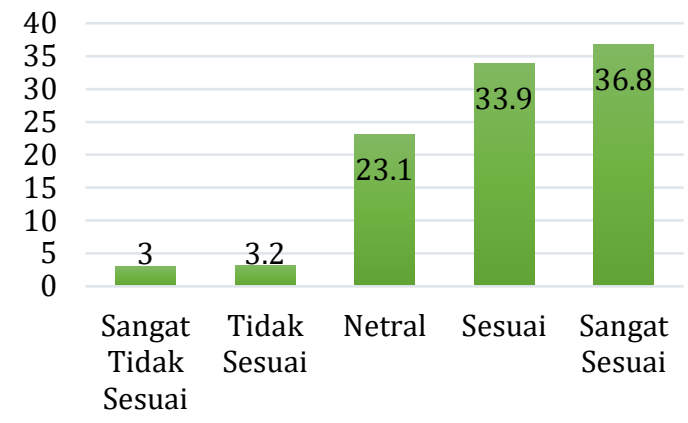

- Persentase Banyaknya Respon

Taat pada aturan pencegahan yang bersifat persuasif. Gambar 13 menggambarkan penilaian responden terhadap regulasi terkait upaya pencegahan penyakit. Responden memiliki tingkat kewaspadaan yang cenderung tinggi terhadap COVID-19 $(3,44)$. Oleh karena itu, responden juga cenderung menganggap perlunya langkah-langkah keamanan yang diberlakukan untuk mencegah penyebaran COVID-19 $(4,43)$. Misalnya, menindak secara tegas orang-orang yang tidak menjalankan protokol kesehatan serta menutup tempat-tempat yang berpotensi menjadi tempat berkumpul (Agustino, 2020; Juaningsih, Consuello, Tarmidzi, \& NurIrfan, 2020).

Langkah pengamanan yang telah dilakukan dianggap telah cukup memadai $(3,56)$, tetapi dinilai masih kurang tepat waktunya $(2,93)$. Kemungkinan besar responden menganggap bahwa upaya pencegahan dan pengamanan dianggap terlambat. Meskipun demikian, Gambar 14 menunjukkan bahwa sebagian besar responden $(72,8 \%)$ mengaku telah sangat patuh pada aturan-aturan pencegahan yang telah ditetapkan otoritas pemerintah.

\section{Gambar 13}

Persepsi kewaspadaan dan keamanan.

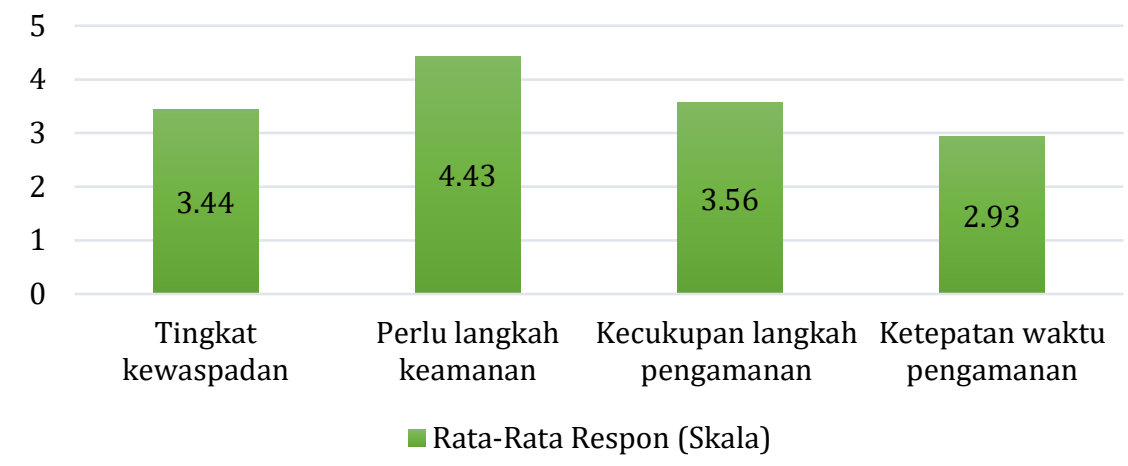


Gambar 14

Mengikuti aturan pencegahan.

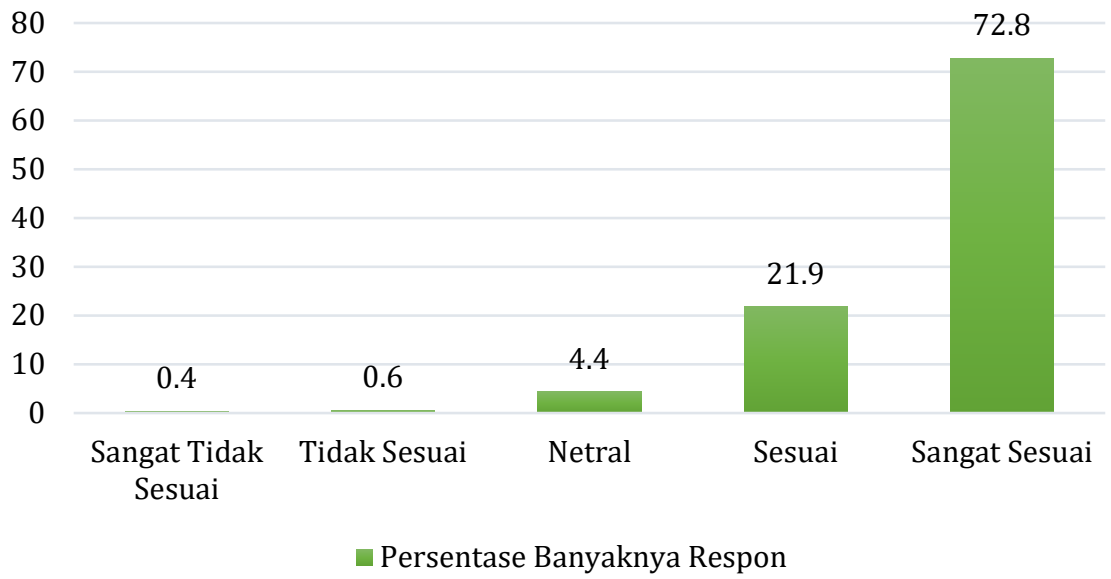

Beberapa upaya penanganan penyebaran virus COVID-19 telah dilakukan oleh pihak berwenang dengan memberi berbagai petunjuk ataupun dengan menerapkan metode pemaksaan. Responden menilai kedua strategi tersebut penting, dapat dilaksanakan, dan dipatuhi. Namun, mereka cenderung lebih setuju dengan cara penanganan yang lebih persuasif, seperti memberi arahan atau petunjuk $(4,64)$, dibandingkan dengan cara paksaan $(4,46)$; t $(542)=6,87 ; \mathrm{p}<$ 0,05; lihat Gambar 15.

\section{Gambar 15}

Memilih upaya persuasif sesuai petunjuk dibandingkan dengan paksaan.

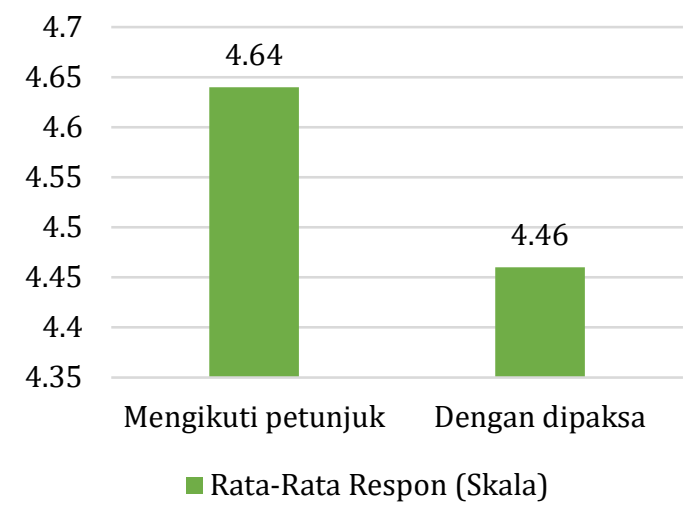

Lebih lanjut, berkenaan dengan upaya pencegahan dan penanggulangan wabah, ditemukan bahwa responden akan mengikuti mayoritas orang, dan juga melakukan tindakan yang menunjukkan solidaritas. Dalam hal ini, responden menilai keduanya diperlukan. Namun, mereka lebih mengutamakan solidaritas $(4,34)$ daripada mayoritas $(3,6)$; t $(542)=14,07 ; \mathrm{p}<0,05$; lihat Gambar 16.

\section{Gambar 16}

Memilih upaya yang menunjukkan solidaritas dibandingkan mengikuti mayoritas.

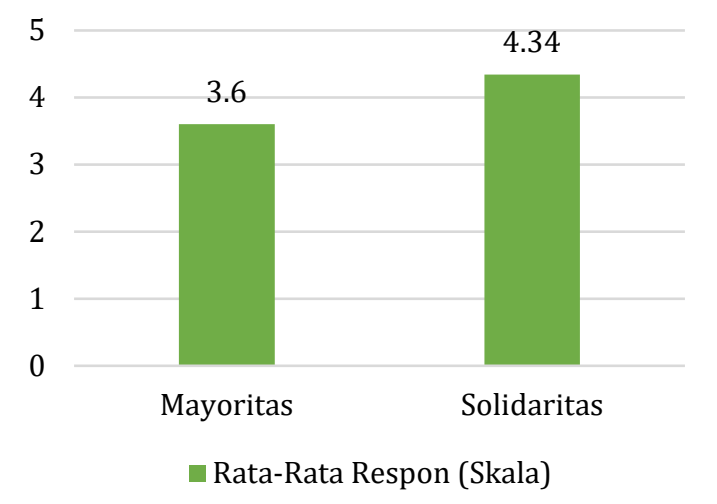


Partisipasi dalam upaya perlindungan terhadap wabah COVID-19. Selain upaya pencegahan dan penanganan wabah, upaya perlindungan terhadap wabah COVID-19 dilakukan melalui upaya mandiri maupun bersama-sama. Kedua hal tersebut dianggap sangat penting oleh responden. Meskipun demikian, upaya bersama atau kolektif $(4,63)$ dinilai lebih penting dari pada upaya sendiri $(4,29)$; $t(542)=8,64 ; p<0,05$; lihat Gambar 17.

\section{Gambar 17}

Mementingkan upaya bersama dibandingkan upaya sendiri

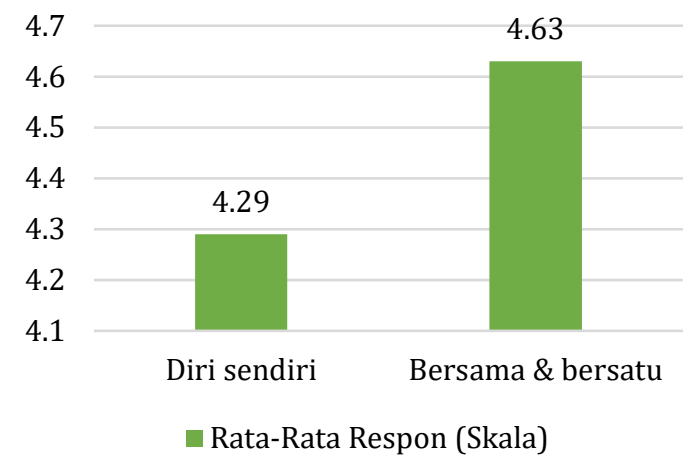

\section{Diskusi}

Data di atas menjabarkan beberapa langkah yang dilakukan oleh masyarakat Indonesia dalam merespon wabah COVID-19. Terdapat upaya-upaya yang dilakukan secara individual dan ada upayaupaya yang bersifat kolektif. Di bagian ini, kami akan membahas lebih lanjut mengenai proses adaptasi pada dua level ini.

\section{Adaptasi individual}

Secara umum, masing-masing individu melakukan proses adaptasi yang dapat dikategorikan sebagai adaptasi aktif dan adaptasi pasif.

Adaptasi aktif. Adaptasi aktif terhadap pandemi dapat dilakukan baik secara kognitif maupun emosional yang lebih lanjut dapat dibedakan menjadi dua. Adaptasi aktif konstruktif dilakukan secara intensional dan dimanifestasikan dalam bentuk perilaku yang memiliki konsekuensi positif. Sebaliknya, adaptasi bersifat aktif-destruktif dapat diwujudkan dalam perilaku yang memiliki konsekuensi negatif bagi pelakunya. Berkaitan dengan strategi koping, adaptasi aktif-konstruktif dapat mengarah pada perubahan, sementara aktif-destruktif dapat mengarah pada penghindaran (Rabenu \& Yaniv, 2017).
Intensitas penggunaan media sosial yang semakin tinggi. Hasil penelitian ini menunjukkan bahwa internet menjadi sumber informasi terkait COVID-19 yang dapat diandalkan. Hal ini merefleksikan bahwa salah satu upaya masyarakat Indonesia untuk beradaptasi secara aktifkonstruktif terhadap COVID-19 ini adalah dengan mencari informasi melalui internet, termasuk juga media sosial. Kemungkinan ini besar mengingat Indonesia tercatat sebagai negara dengan penggunaan internet yang tinggi (Nasir, dkk., 2020). Media sosial telah menjadi media diseminasi pencegahan infeksi dan promosi kesejahteraan psikologis yang cepat, seperti melalui infografis yang cenderung menarik perhatian dan mudah dipahami oleh masyarakat (Chan, dkk., 2020). Penelitian Huynh (2020) juga menemukan bahwa media sosial dapat meningkatkan persepsi risiko pandemi COVID-19 di Vietnam yang kemudian dapat membantu memperlambat penyebarannya. Di Indonesia sendiri, jaringan informasi melalui media sosial tersebar luas dan menjangkau semua lapisan masyarakat. Beberapa petunjuk tentang penggunaan hand sanitizer dan disinfektan menyebar di kalangan masyarakat, juga beberapa aktivitas seperti berjemur di bawah terik matahari pagi (Djalante, dkk., 2020).

Lebih lanjut, hasil penelitian juga menunjukkan bahwa penggunaan media sosial sebagai ganti tatap muka untuk berelasi sangat tinggi, sejalan dengan tingginya angka penggunaan media sosial di Indonesia. Teknologi digital dapat berfungsi sebagai media untuk mendukung kesehatan fisiologis dan psikologis serta pengembangan diri pribadi (Diefenbach, 2018). Pandemi COVID-19 telah membuat masyarakat Indonesia melakukan penyesuaian cara berelasi yang memberikan efek yang positif, terutama dalam aspek dukungan sosial di tengah pembatasan sosial yang ada.

Selain bersifat konstruktif, terdapat juga pola adaptasi aktif yang destruktif kaitannya dengan penyebaran informasi. Internet, khususnya media sosial, dapat menjadi media penyebaran informasi yang keliru dan tidak benar. Istilah infodemik diperkenalkan untuk menguraikan bahaya fenomena kesalahan informasi selama pengelolaan wabah virus karena informasi itu dapat mempercepat proses epidemi dengan memengaruhi dan memecah respons sosial (Cinelli, dkk., 2020). Pandemi COVID-19 juga memicu penyebaran Informasi berupa rumor, desas-desus, tipuan atau informasi yang salah (hoaks) dan teori konspirasi yang menyesatkan sehingga menyebabkan ketakutan, rasisme, hingga pembelian masker secara massal (Depoux, dkk., 2020; Tasnim, dkk., 2020). Apalagi beberapa pihak cenderung berbagi klaim-klaim yang keliru tentang COVID-19 karena kurangnya proses berpikir 
analitis mengenai keakuratan konten tersebut ketika hendak dibagikan (Pennycook, dkk., 2020).

Sudah disebutkan pula bahwa penggunaan media sosial sebagai ganti tatap muka memang memberikan manfaat tersendiri pada masa pandemi ini. Meskipun demikian, terdapat juga dampak lainnya yang cenderung destruktif seperti memunculkan potensi digital overconsumption, yang dapat mengarahkan pada stres hingga kecemasan sehingga dapat menganggu kesehatan mental. Misalnya, penelitian Rahardjo, Qomariyah, Mulyani, dan Andriani (2020) menunjukkan bahwa kelebihan informasi memiliki pengaruh terhadap social media fatigue pada mahasiswa yang belajar di rumah selama pandemi COVID-19.

Menaati Regulasi Pemerintah: Pelaporan COVID-19 dan 3M. Selain bentuk pencarian dan penyebaran informasi, respons yang dapat menunjukkan proses adaptasi konstruktif adalah masyarakat akhirnya menjalankan himbauan pemerintah, salah satunya untuk mempraktikkan protokol kesehatan. Literatur menunjukkan bahwa orang yang cemas tentang infeksi pada masa pandemi biasanya berusaha keras untuk melindungi diri mereka. Hal ini diantaranya melibatkan penghindaran rangsangan yang berhubungan dengan infeksi, termasuk orang, tempat, dan hal-hal yang berkaitan dengan penyakit (Taylor, 2019). Di Indonesia, ada tiga perubahan perilaku publik yang paling umum sebagai respons terhadap pandemi ini, yaitu tinggal di rumah, lebih sering mencuci tangan, dan menerapkan jarak sosial (social distancing). Proses isolasi diri yang merupakan norma baru karena hampir tidak pernah menjadi cerminan umum budaya Indonesia, juga telah diterapkan (Djalante, dkk., 2020).

Hasil penelitian ini menunjukkan bahwa responden cenderung akan melaporkan orang yang memiliki jarak personal yang dekat, seperti keluarga serta orang yang dikenalnya, dibandingkan orang asing atau orang yang tak dikenalnya. Temuan ini sejalan dengan adanya kekhawatiran kehilangan orang-orang yang dicintai dan mereka kenal. Van Bavel, dkk. (2020) menuliskan bahwa pengalaman ketakutan dan ancaman memiliki konsekuensi tidak hanya pada cara seseorang berpikir tentang diri mereka sendiri, melainkan juga tentang perasaan mereka dan cara bereaksi terhadap orang lain, khususnya out-group. Misalnya, terancam penyakit sering dikaitkan dengan tingkat etnosentrisme yang lebih tinggi; ketakutan yang besar; dan ancaman yang dirasakan terkait dengan intoleransi yang lebih besar dan sikap menghakimi kelompok lain. Meskipun demikian, di Indonesia, pelaporan yang terkait prasangka tidak terlalu menonjol, karena pelaporan lebih dikaitkan dengan keamanan dan kesehatan orang terdekat.

Proses adaptasi yang cenderung destruktif juga dapat dilihat dari orang yang tidak sepenuhnya patuh terhadap protokol kesehatan. Pada penelitian ini, penggunaan masker di luar rumah masih belum menunjukkan konsistensi. Pada masa pandemi, cara orang-orang bereaksi akan beragam, mulai dari ketakutan, ketidakpedulian hingga fatalisme (Honingsbaum; Pettigrew; Wheaton, Abramowitz, Berman, Fabricant, \& Olatunji dalam Taylor, 2019). Salah satu faktor yang dapat mempengaruhi perilaku seseorang adalah persepsi risiko dan emosi (Van Bavel, dkk., 2020). Ketika individu merasakan emosi negatif terkait penggunaan masker, ditambah dengan informasi yang mengatakan bahwa masker memang tetap tidak efektif untuk mencegah penularan, kemungkinan orang tersebut tidak akan menggunakannya.

Adaptasi pasif. Selain adaptasi aktif, adaptasi juga dapat berupa suatu proses pasif yang mana individu secara intensional menerima situasi dan pasrah; ditandai dengan pengharapan atas hal eksternal di luar diri mereka. Hasil riset menunjukkan bahwa Pandemi telah membuat orang-orang di Indonesia menjadi lebih mendekatkan diri kepada Tuhan dan mempercayai rencana Tuhan. Hal ini dapat dijelaskan juga sebagai mekanisme koping religius yang dikaitkan dengan aspek spiritualitas. Berdoa adalah wujud umum dari mekanisme koping religius tersebut. Secara global, pada masa pandemik ini terdapat kecenderungan orang-orang berdoa untuk mengatasi kesulitan. Lebih dari setengah populasi dunia telah berdoa agar krisis Coronavirus ini berakhir (Bentzen, 2020).

Indonesia sendiri merupakan negara dengan mayoritas penduduknya memeluk agama yang mempraktikkan ritual-ritual berdoa. Salah satu bentuk ritual tersebut adalah tradisi mbeleh wedhus kendhit sebagai sarana tolak bala di masa pandemi COVID-19, yang berisi ritual penyembelihan kambing hitam dan pelaksanaan doa bersama di lapangan (Yusuf \& Basyid, 2020). Kecenderungan untuk berdoa juga dapat merefleksikan adanya harapan yang mendukung optimisme. Hasil penelitian ini menunjukkan adanya keyakinan recovery masyarakat yang tinggi terkait efek dari pandemi ini, yang juga dapat dikaitkan dengan nilai-nilai yang dianut masyarakat, seperti nilai agama dan budaya.

Adaptasi pasif tidak selamanya memberikan dampak negatif jika dikaitkan dengan aspek spiritualitas dan religiusitas. Aspek ini berhubungan dengan kebiasan dan pengalaman hidup seseorang sehari-hari, termasuk respons seseorang dalam menghadapi pengalaman atau keja- 
dian traumatis (Ren, 2012). Spiritualitas dan religiusitas menjadi sumber daya koping yang penting; menfasilitasi adaptasi setelah krisis (Greeff \& Loubser, 2008; Subandi, dkk., 2014).

\section{Adaptasi kolektif}

Selain adaptasi yang bersifat individual, manusia juga memiliki kemampuan melakukan adaptasi secara berkelompok ketika berada dalam kondisi terancam. Dalam situasi penyebaran wabah di Indonesia, individu juga dapat menunjukkan pola pikir zero-sum yaitu pola pikir dalam konteks kompetisi yang mana keuntungan bagi seorang individu merupakan kerugian bagi individu lain. Jadi, individu akan cenderung memikirkan keselamatan diri dan keluarganya daripada harus bekerjasama dalam skala yang lebih besar (Boyer \& Petersen, 2018). Pola pikir zerosum juga tampak dalam beberapa hal seperti langkanya hand sanitizer dan masker yang seringkali terjadi pada kondisi wabah karena pembelian dalam jumlah besar oleh orang-orang tertentu. Meskipun demikian, hal ini dapat diminimalkan dengan kecenderungan masyarakat untuk melakukan upaya bersama dalam menghadapi pandemi.

Keutamaan upaya bersama. Masyarakat Indonesia cenderung mengutamakan upaya bersama dibandingkan upaya sendiri-sendiri dalam perlindungan terhadap COVID-19. Upaya bersama yang dipentingkan tersebut dapat berkaitan dengan budaya kolektif masyarakat Indonesia. Adanya rasa identitas bersama dan tujuan bersama dapat didorong oleh budaya kolektif tersebut dan mendesak untuk bertindak demi kebaikan bersama (Van Bavel, dkk., 2020).

Adaptasi psikologis pada level kelompok mengarah pada koping kolektif. Lyon, dkk (dalam Wlodarczyk, dkk., 2016) juga mencetuskan istilah communal coping, yaitu sebuah proses yang mana tindakan dalam menangani wabah dilakukan secara kolektif dengan adanya perasaan bertanggung jawab untuk menyelesaikan masalah bersama. Communal coping sejalan dengan model sosiokultural stres, koping, dan adaptasi Aldwin (lihat Tandoc \& Takahashi, 2017), yang oleh Kuo (2013) juga disebut sebagai teori sosiokultural dari koping kolektif.

Koping kolektif sebagai bentuk adaptasi bersama ini menjadi penting pada masa pandemi. Dalam kondisi jangka panjang, kerjasama antar individu dalam masyarakat sangat diperlukan, bahkan setiap pihak dalam skala internasional juga saling berkolaborasi menangani wabah karena dalam kondisi seperti pandemi setiap pihak akan terkena dampak negatif (van Bavel, dkk, 2020). Dalam budaya kolektif, masya- rakat memiliki ikatan yang kohesif dan setiap individu perlu untuk menjaga loyalitas terhadap kelompoknya ataupun memberikan perhatian pada masyarakat tempat dirinya berada (Hofstede \& Hofstede, 2005). Karakter tersebut dapat menjadi pertimbangan dalam proses adaptasi aktif kolektif.

Solidaritas (reflektif) sebagai esensi koping kolektif. Penanganan bersama tersebut mengutamakan solidaritas dibandingkan sekadar upaya yang dilakukan bersama oleh mayoritas orang-orang. Alwi (2020) menemukan bahwa kebijakan pembatasan atau jarak sosial (social distancing) secara perlahan telah mengubah pola interaksi dalam masyarakat, sehingga diperlukan solidaritas multikultural. Solidaritas dapat merujuk pada keadaan sekelompok orang atau masyarakat yang dicirikan dengan adanya keterikatan yang timbal-balik, koneksi, atau ketergantungan (Jaeggi, 2001). Dean (dalam Juul, 2010) mengemukakan beberapa jenis solidaritas, yaitu solidaritas afektif yang didasarkan pada hubungan dekat dan tanggung jawab moral, yang dibatasi pada mereka yang secara emosional terhubung (contohnya, anggota keluarga dan teman). Adanya solidaritas afektif ini yang juga dapat mendorong seseorang cenderung melindungi keluarganya atau orang terdekatnnya, seperti pada pelaporan COVID-19 dalam penelitian ini.

Selain itu, ada yang diistilahkan solidaritas reflektif; didefinisikan sebagai harapan bersama karena adanya orientasi tanggung jawab terhadap hubungan antar individu (Dean dalam Juul, 2010). Pada masa pandemik, solidaritas reflektif ini yang dapat dikembangkan tanpa adanya batasbatas hubungan kekerabatan dan kelompok (ingroup) mengingat setiap orang berada dalam kerentanan bersama. Dengan demikian, solidaritas reflektif ini dapat mendukung toleransi dalam masyarakat di masa pandemik karena solidaritas yang dikembangkan cenderung mengarah pada solidaritas universal dibandingan solidaritas pada in-group semata. Dalam hal ini, kesadaran untuk mempraktikkan perilaku hidup bersih dan sehat tidak lagi hanya didasari pertimbangan untuk melindungi diri sendiri dan keluarga dekat atau kelompok, melainkan juga melindungi orang lain sehingga pertimbangannya adalah kesehatan masyarakat (Cheng, dkk., 2020).

Dengan mengurangi intoleransi melalui solidaritas reflektif tersebut, bukan hanya penyebaran virus yang dapat dicegah, melainkan juga kesenjangan ekonomi yang dapat tercipta akibat pandemi. Solidaritas reflektif yang dikembangkan dapat mendorong upaya bersama untuk menolong pihak yang terdampak, seperti melalui donasi bahan makanan, santunan, dan sebagainya, yang juga sudah terlaksana di Indonesia 
(Herlan, 2020). Solidaritas reflektif tersebut dapat menguatkan koping pada level kolektif yang memberikan konsekuensi positif bagi masyarakat.

Berbagai aksi solidaritas tersebut juga didukung oleh penggunaan media melalui penyebaran informasi donasi (Kristianto, Ramadhan, \& Marsetyo, 2020). Ada gerakan yang dilakukan oleh jurnalis dan industri media di Indonesia yang bertujuan misalnya untuk menyebarkan berbagai konten pendidikan dalam skala besar sebagai upaya menghambat penyebaran virus (Djalante, dkk., 2020.) Hal ini dapat menunjukkan adanya bentuk adaptasi aktif yang konstruktif secara kolektif; individu ataupun pihak-pihak tertentu memanfaatkan proses komunikasi dan mobilisasi hubungan sosial (Wlodarczyk, dkk., 2016) dalam proses adaptasi menghadapi COVID-19.

\section{Kesimpulan}

Individu akan melakukan mekanisme adaptasi apabila menghadapi stimulus-stimulus ancaman dari lingkungan, termasuk pandemik COVID-19, yang mengakibatkan perubahan terhadap tatanan kehidupannya. Seperti halnya tinjauan psikologis terhadap adaptasi, penelitian ini menunjukkan berbagai bentuk adaptasi individual yang dilakukan, baik berupa adaptasi aktif yang bersifat konstruktif maupun yang bersifat destruktif. Penelitian ini juga menemukan bahwa pola adaptasi pasif tidak selalu bersifat destruktif, tapi justu dapat bersifat konstruktif, seperti berbagai bentuk doa yang dapat mendukung optimisme menghadapi dampak COVID-19 di Indonesia. Temuan menarik lainnya adalah bahwa adaptasi individual bukan satu-satunya bentuk adaptasi yang dilakukan, melainkan juga berkembangnya adaptasi kolektif atau komunal yang cukup menonjol; dengan solidaritas, terutama solidaritas reflektif, sebagai esensi dari upaya bersama. Pengembangan adaptasi kolektif juga didukung nilai-nilai kolektif masyarakat Indonesia.

\section{Keterbatasan dan Saran}

Penelitian ini merupakan penelitian eksplorasi sehingga variabel-variabel yang digali dalam kuesioner tidak dibatasi. Dengan demikian, penelitian yang lebih spesifik terkait respons adaptif masyarakat maupun variabel lainnya terkait dengan pandemi COVID-19 dapat dilakukan lebih lanjut. Temuan-temuan dari hasil penelitian ini juga dapat menjadi dasar untuk menentukan aspek dan variabel yang akan diteliti lebih lanjut. Sejalan dengan tujuannya, hasil dari penelitian ini pun dipaparkan secara deskriptif. Dengan demikian, penelitian lebih lanjut dapat berfokus pada penelitian model prediktif yang mengkaji keterkaitan antar variabel yang akan diteliti.

\section{Daftar Pustaka}

Agustino, L. (2020). Analisis Kebijakan Penanganan Wabah Covid-19: Pengalaman Indonesia. Jurnal Borneo Administrator, 16(2), 253-270. doi:10.24258/jba.v16i2.685

Alwi, A. (2020). Solidaritas Masyarakat Multikultural dalam Menghadapi Covid-19. Prosiding Nasional Covid-19, 33-36.

Atchison, C., Bowman, L., Eaton, J., Imai, N., Redd, R., Pristera, P., \& Ward, H. (2020). Report 10: Public response to UK Government recommendations on COVID-19: Population survey, 17-18 March 2020. Imperial College London, 20.

Becker, E. (2007). The denial of death. Simon and Schuster.

Bentzen, J. (2020). In crisis, we pray: Religiosity and the COVID-19 pandemic.

Berg-Weger, M., \& Morley, J. E. (2020). Loneliness and social isolation in older adults during the Covid-19 pandemic: Implications for gerontological social work. Springer.

Boyer, P., \& Petersen, M. B. (2018). Folkeconomic beliefs: An evolutionary cognitive model. Behavioral and Brain Sciences, 41.

Chan, A. K. M., Nickson, C. P., Rudolph, J. W., Lee, A., \& Joynt, G. M. (2020). Social media for rapid knowledge dissemination: Early experience from the COVID-19 pandemic. Anaesthesia. https://doi.org/10.1111/anae.15057

Cheng, K. K., Lam, T. H., \& Leung, C. C. (2020). Wearing face masks in the community during the COVID-19 pandemic: Altruism and solidarity. The Lancet, $0(0)$. https://doi.org/10.1016/S01406736(20)30918-1

Cinelli, M., Quattrociocchi, W., Galeazzi, A., Valensise, C. M., Brugnoli, E., Schmidt, A. L., Zola, P., Zollo, F., \& Scala, A. (2020). The COVID-19 Social Media Infodemic. ArXiv:2003.05004 [Nlin, Physics:Physics]. http://arxiv.org/abs/2003.05004

Depoux, A., Martin, S., Karafillakis, E., Preet, R., Wilder-Smith, A., \& Larson, H. (2020). The pandemic of social media panic travels faster than the COVID-19 outbreak. Journal of Travel Medicine, 27(3). https://doi.org/10.1093/jtm/taaa031

Diefenbach, S. (2018). The Potential and Challenges of Digital Well-Being Interventions: Positive Technology Research and Design in Light of the BitterSweet Ambivalence of Change. Frontiers in Psychology, $\quad 9, \quad 331$. https://doi.org/10.3389/fpsyg.2018.0033 1 
Djalante, R., Lassa, J., Setiamarga, D., Sudjatma, A., Indrawan, M., Haryanto, B., Mahfud, C., Sinapoy, M. S., Djalante, S., Rafliana, I., Gunawan, L. A., Surtiari, G. A. K., \& Warsilah, H. (2020). Review and analysis of current responses to COVID-19 in Indonesia: Period of January to March 2020. Progress in Disaster Science, 6, 100091. https://doi.org/10.1016/j.pdisas.2020.100 091

Folkman, S., \& Moskowitz, J. T. (2000). Positive affect and the other side of coping. American psychologist, 55(6), 647.

Furr R.M., \& Bacharach, V.R. (2013). "Psychometrics. An Introduction" (2nd ed.), Los Angelers: Sage.

Gerhold, L. (2020). COVID-19: Risk perception and coping strategies.

Gerungan, W.A. 2006. Psikologi Sosial. Bandung: Eresco.

Greeff, A. P., \& Loubser, K. (2008). Spirituality as a Resiliency Quality in Xhosa-speaking Families in South Africa. Journal of Religion and Health, 47(3), 288-301. https://doi.org/10.1007/s10943-0079157-7

Helson, H. (1964). Adaptation-level theory. Harper \& Row.

Herlan, H., Efriani, E., Sikwan, A., Hasanah, H., Bayuardi, G., Listiani, E. I., \& Yulianti, Y. (2020). Keterlibatan Akademisi Dalam Menanggulangi Dampak Covid-19 Terhadap Masyarakat Melalui Aksi Berbagi Sembako. JCES (Journal of Character Education Society), 3(2), 267-277.

Ho, C. S., Chee, C. Y., \& Ho, R. C. (2020). Mental health strategies to combat the psychological impact of COVID-19 beyond paranoia and panic. Ann Acad Med Singapore, 49(1), 1-3.

Hofstede, G., Hofstede, G. J., \& Minkov, M. (2005). Cultures and organizations: Software of the mind (Vol. 2). Mcgraw-hill New York.

Huynh, T. L. (2020). The COVID-19 risk perception: A survey on socioeconomics and media attention. Econ. Bull, 40(1), 758764.

Jaeggi, R. (2001). Solidarity and Indifference. Dalam R. ter Meulen, W. Arts, \& R. Muffels (Ed.), Solidarity in Health and Social Care in Europe (hlm. 287-308). Springer Netherlands.

https://doi.org/10.1007/978-94-0159743-2_12

Juaningsih, I. N., Consuello, Y., Tarmidzi, A., \& NurIrfan, D. (2020). Optimalisasi Kebijakan Pemerintah dalam penanganan Covid-19 terhadap Masyarakat Indonesia. SALAM: Jurnal Sosial dan Budaya Syar-i, 7(6), 509-
518.

Juul, S. (2010). Solidarity and Social Cohesion in Late Modernity: A Question of Recognition, Justice and Judgement in Situation. European Journal of Social Theory, 13(2), 253-269.

https://doi.org/10.1177/1368431010362 296

Kramer, A. D., Guillory, J. E., \& Hancock, J. T. (2014). Experimental evidence of massivescale emotional contagion through social networks. Proceedings of the National Academy of Sciences, 111(24), 8788-8790.

Kristamuliana, \& Simak, V. F. (2020). TINGKAT PENGETAHUAN DAN STRATEGI KOPING MASYARAKAT INDONESIA MENGHADAPI PANDEMI COVID-19. Jurnal Ilmiah Keperawatan Imelda, 6(2), 158163.https://doi.org/10.2411/jikeperawata n.v6i 2.413

Kristianto, K., Ramadhan, A. B., \& Marsetyo, F. D. Media Sosial dan Connective Action: Studi Kasus Penggunaan Twitter sebagai Ruang Solidaritas selama Pandemi COVID-19. Journal of Social Development Studies, 2(1), 1-13.

Kuo, B. C. H. (2013). Collectivism and coping: Current theories, evidence, and measurements of collective coping. International Journal of Psychology, 48(3), 374-388.

https://doi.org/10.1080/00207594.2011. 640681

LeDoux, J. (2012). Rethinking the emotional brain. Neuron, 73(4), 653-676.

Li, S., Wang, Y., Xue, J., Zhao, N., \& Zhu, T. (2020). The impact of COVID-19 epidemic declaration on psychological consequences: A study on active Weibo users. International journal of environmental research and public health, 17(6), 2032.

Lopez, C. E., Vasu, M., \& Gallemore, C. (2020). Understanding the perception of COVID-19 policies by mining a multilanguage Twitter dataset. arXiv preprint arXiv:2003.10359.

Masitoh, A. (2020). Strategi Koping Siswa dalam Menghadapi Stres Akademik di Era Pandemi Covid-19. Academica: Journal of Multidisciplinary Studies, 4(2), 185-198.

Mobbs, D., Hagan, C. C., Dalgleish, T., Silston, B., \& Prévost, C. (2015). The ecology of human fear: Survival optimization and the nervous system. Frontiers in neuroscience, 9, 55.

Nasir, N. M., Baequni, B., \& Nurmansyah, M. I. (2020). MISINFORMATION RELATED TO COVID-19 IN INDONESIA. Jurnal Administrasi Kesehatan Indonesia, 8(2), 51. https://doi.org/10.20473/jaki.v8i2.2020.5 1-59 
Nasrudin, N., Kusumaningrum, U. A., \& Prihaninuk, D. (2020). Dampak isolasi sosial selama pandemi covid 19 terhadap remaja: aktifitas, emosional, stress-adaptasi dan strategi koping remaja selama pandemi covid-19 di indonesia. Jurnal EDUNursing, 4(2), 110-121.

Nasir, A., \& Muhith, A. (2011). Dasar-dasar keperawatan jiwa: pengantar dan teori. Jakarta: Salemba Medika.

Pennycook, G., McPhetres, J., Zhang, Y., \& Rand, D. (2020). Fighting COVID-19 misinformation on social media: Experimental evidence for a scalable accuracy nudge intervention. PsyArXiv Preprints, 10.

Rabenu, E., \& Yaniv, E. (2017). Psychological resources and strategies to cope with stress at work. International Journal of Psychological Research, 10(2), 8-14. https://doi.org/10.21500/20112084.2698

Rahardjo, W., Qomariyah, N., Mulyani, I., \& Andriani, I. (2020). Social Media Fatigue pada Mahasiswa di Masa Pandemi COVID19: Peran Neurotisisme, Kelebihan Informasi, Invasion of Life dan Kecemasan. Jurnal Psikologi Sosial. http://jps.ui.ac.id/index.php/jps/article/vi ew $/ 220$

Ren, Z. (2012). Spirituality and community in times of crisis: Encountering spirituality in indigenous trauma therapy. Pastoral Psychology, 61(5-6), 975-991.

Sarafino, E. P., \& Smith, T. W. (2014). Health psychology: Biopsychosocial interactions. John Wiley \& Sons.

Shultz, j. M., Baingana, F., \& Neria, Y. (2015). The 2014 Ebola outbreak and mental health: Current status and recommended response. Journal of the American Medical Association, 313, 567-568. doi:10.1001/jama.2014.17934

Simonet, G., \& Duchemin, E. (2010). The concept of adaptation: Interdisciplinary scope and involvement in climate change. 10.

Smith, M. M., Saklofske, D. H., Keefer, K. V., \& Tremblay, P. F. (2016). Coping Strategies and Psychological Outcomes: The Moderating Effects of Personal Resiliency. The Journal of Psychology, 150(3), 318-332. https://doi.org/10.1080/00223980.2015. 1036828

Subandi, M. A., Achmad, T., Kurniati, H., \& Febri, R. (2014). Spirituality, gratitude, hope and post-traumatic growth among the survivors of the 2010 eruption of Mount Merapi in Java, Indonesia. Australasian Journal of
Disaster and Trauma Studies, 18(1), 19.

Tandoc, E. C., \& Takahashi, B. (2017). Log in if you survived: Collective coping on social media in the aftermath of Typhoon Haiyan in the Philippines. New Media \& Society, 19(11), 1778-1793. https://doi.org/10.1177/1461444816642 755

Tasnim, S., Hossain, M. M., \& Mazumder, H. (2020). Impact of rumors or misinformation on coronavirus disease (COVID-19) in social media. Journal of Preventive Medicine and Public Health.

Taylor, S. (2019). The Psychology of Pandemics: Preparing for the Next Global Outbreak of Infectious Disease. Cambridge Scholars Publishing, 179.

Van Bavel, J. J., Baicker, K., Boggio, P. S., Capraro, V., Cichocka, A., Cikara, M., Crockett, M. J., Crum, A. J., Douglas, K. M., \& Druckman, J. N. (2020). Using social and behavioural science to support COVID-19 pandemic response. Nature Human Behaviour, 1-12.

World Health Organization, WHO. (2020, June). https://www.who.int/emergencies/diseases /novel-coronavirus-2019. Retrieved from https://www.who.int/emergencies/diseas es/novel-coronavirus-2019

Wise, T., Zbozinek, T. D., Michelini, G., \& Hagan, C. C. (2020). Changes in risk perception and protective behavior during the first week of the COVID-19 pandemic in the United States.

Wlodarczyk, A., Basabe, N., Páez, D., Amutio, A., García, F. E., Reyes, C., \& Villagrán, L. (2016). Positive effects of communal coping in the aftermath of a collective trauma: The case of the 2010 Chilean earthquake. European Journal of Education and Psychology, 9(1), 9-19.

https://doi.org/10.1016/j.ejeps.2015.08.0 01

Yang, J., \& Andriesse, E. (2020). Cumulative adaptation and linkages among adaptation, coping and vulnerability: A case of riverside slum households in Phnom Penh, Cambodia. Environment and Urbanization, 095624782097834 https://doi.org/10.1177/0956247820978 347

Yusuf, M., \& Basyid, A. (2020). Tradisi "Mbeleh Wedhus Kendhit" Sebagai Sarana Tolak Balak di Masa Pandemi Covid-19. Sosial Budaya, 17(2), 149-159. https://doi.org/10.24014/sb.v17i2.11272 